\title{
TESTING TWO ISOLATES OF Diaporthe/Phomopsis helianthi IN A POPULATION OF SUNFLOWER RECOMBINANT INBRED LINES
}

\author{
S. Jocić ${ }^{*}$, N. Lačok ${ }^{1}$, V. Miklić ${ }^{1}$, D. Škorić ${ }^{1}$ and Y. Griveau ${ }^{2}$ \\ ${ }^{1}$ Institute of Field and Vegetable Crops, Maksima Gorkog 30, 21000 Novi Sad, \\ Serbia and Montenegro \\ 2 INRA UMR Diversite et Genome des Plantes Cultivees, Domaine de Melgueil, \\ F-34130, Mauguio, France
}

Received: July 10, 2004 Accepted: November 22, 2004

SUMMARY

\begin{abstract}
Development of new, more aggressive isolates of Phomopsis helianthi in Serbia and Montenegro has been investigated. Two isolates of Phomopsis helianthi, Yu 4 and Yu 12, had been found on the stem of NS-H-45, a highly tolerant sunflower hybrid. The isolate Yu 4 was isolated in the northern part of the Vojvodina Province, a region where Phomopsis typically occurs. The isolate Yu 12 comes from the southern part of the Vojvodina Province, a region along the Danube River, which suffered an intensive outbreak of Phomopsis in 1997. A preliminary study of the isolates showed that these two isolates were significantly different for radial growth in Petri dish. A test was thus made with recombinant inbred lines in the $\mathrm{F}_{9}$ generation developed from the cross of LR4-17 (inbred line with high tolerance to Phomopsis) and HA-89 (susceptible inbred line). Experiments were conducted in the greenhouse, inoculating plant leaf tips with the mycelium of the fungus. The test showed that there were no significant differences between the two isolates, $\mathrm{Yu} 4$ and $\mathrm{Yu} 12$. It was concluded that the intensive attack recorded in 1997 along the Danube River occurred due to exceptionally favorable environmental conditions for the development of the disease.
\end{abstract}

Key words: sunflower, Diaporthe/Phomopsis helianthi, recombinant inbred lines

\section{INTRODUCTION}

Stem canker caused by Diaporthe/Phomopsis helianthi Muntañola-Cvetković et al. was the most damaging disease in Europe in last twenty years. When meteorological conditions during sunflower growing season are favorable for disease development, considerable reductions in seed yield and oil content result.

\footnotetext{
* Corresponding author: Phone: +381 214898 403, Fax: +38121413833, e-mail: sinjocic@ifvens.ns.ac.yu
} 
First identified in Serbia and Montenegro in 1980 by Mihaljčević et al. (1980), the new species was described as Diaporthe helianthi Muntañola-Cvetković et al. for the teleomorphic state and Phomopsis helianthi Muntañola-Cvetković et al. for the anamorphic state (Muntañola-Cvetković et al., 1981). Primary infection occurs from ascospores that ooze out from perithecia, formed in overwintered plant residues. Mature ascospores are already found in mid-April, but their full maturity and dissemination occurs at the flowering period of sunflower plants at the end of June and the beginning of July (Mihaljčević et al., 1982).

First symptoms appear in the form of small necrotic blotches on leaf margins. They spread along the lateral veins, reaching the main vein usually after flowering. The symptoms first occur on the bottom leaves, moving gradually up to the $11^{\text {th }}$ pair of leaves. The fungus spreads down the petiole to the stem, where the most characteristic and conspicuous symptoms occur, starting as a brown spot with a black edge in the leaf axil. The spot gradually turns grayish, brownish-gray or grayish-brown, with brownish-black pycnidia forming in the center of the spot. The pathogen softens and destroys the stem tissue, causing plant drying and lodging (Aćimović and Štraser, 1981).

The best way of controlling the fungus is to grow resistant cultivars (Mihaljčević et al., 1982). Commercial hybrids with high tolerance to Diaporthe/Phomopsis helianthi are available since 1985. They were developed from the highly tolerant inbred lines, obtained by Škorić by intercrossing the cultivated sunflower with H. tuberosus, H. argophyllus with H. annuus population Armavirski 9345, and a local population from Morocco. The first highly tolerant hybrids were named NS-H43, NS-H-44 and NS-H-45.

Genetic studies have not rendered a definitive answer on the mode of inheritance and number of genes that control this tolerance. Škorić (1985) reported that the resistance to Diaporthe/Phomopsis helianthi is most probably controlled by at least two or more complementary genes, and that the mode of inheritance is intermediacy or partial dominance. Tourvieille et al. (1988) found that the resistance might be recessive or polygenic, i.e., dependent on interactions between genes. He also found that different types of resistance seem to act in the plant tissues of leaf and stem. Vranceanu et al. (1992) stated that resistance is primarily controlled by partial dominance and that three genes or gene groups are involved in the resistance, in any case, that there are several genes (3-7) that control it. Langar et al. (1997) observed two kinds of tolerant genotypes: permissive genotypes, which react against the fungus after a long delay, and non-permissive genotypes, which possess the ability to stop fungus development at the very beginning of the attack. That may indicate the existence of different components of Phomopsis resistance, the early response to the pathogen and the late slowdown of the infection corresponding to different genetic factors present in different germplasms. Degener et al. (1999) reported that different types of resistance are active in the plant tissues of leaf and stem, but both types of resistance being mainly controlled by additive gene action. 
Langar et al. (2000) suggested that the resistance in leaf tissue is influenced by one major gene while at least two complex factors influence the resistance in petiole and stem tissues. Sunflower breeders still need more information about the type of inheritance and number of genes involved in Phomopsis resistance.

The Phomopsis attack recorded in 1997 in the area near the Danube River (the Vojvodina Province) was the most intensive epidemic registered after the development of the tolerant hybrids. This situation suggested that more aggressive isolates might have evolved (Maširević et al., 1998). The aim of this study was to check the above hypothesis.

\section{MATERIALS AND METHODS}

A test was made with the $\mathrm{F}_{9}$ generation of 232 recombinant inbred lines (RILs) developed at INRA-SGAP, Mauguio, from a cross LR-4-17 $\times$ HA-89. LR-4-17 is an inbred line with high tolerance to Phomopsis, derived from the resistant hybrid NS$\mathrm{H}-45$ by selfing. HA-89 is a highly susceptible inbred line originating from the openpollinated variety VNIIMK-8931.

D. helianthi inocula were isolated from stems of the highly tolerant hybrid NS$\mathrm{H}-45$. The isolate Yu 4 comes from the northern part of the Vojvodina Province, a region typically prone to Phomopsis attack. The isolate Yu 12 comes from the southern part of the Vojvodina Province, an area along the Danube River in which an intensive Phomopsis epidemic broke out in 1997. The inocula were cultured on $1 \%$ malt medium with $1.5 \%$ agar at $23^{\circ} \mathrm{C} \pm 1^{\circ} \mathrm{C}$, in the darkness.

The RILs were grown in the greenhouse at IFVC, Novi Sad, Serbia and Montenegro. Experiments were conducted in two separate greenhouse compartments, one for each fungal isolate; the same genetic material was used in the both compartments. Normal cultivation practices were applied until the beginning of flowering, when inoculation was made. Environmental conditions in the greenhouse were automatically controlled by an INDAL microprocessor. After infections, plants were grown at $24^{\circ} \mathrm{C} \pm 1^{\circ} \mathrm{C}$ during a $16 \mathrm{~h}$ light period (25,000-40,000 lx supplied by 1,000 W Philips G/92/2 tubes) and at $19^{\circ} \mathrm{C} \pm 1^{\circ} \mathrm{C}$, during an $8 \mathrm{~h}$ dark period. Humidity was daily maintained between $70-80 \%$ by the greenhouse watering system.

Leaves were inoculated before beginning of flowering stage, according to the method described by Tourvieille et al. (1988). Mycelium disks $6 \mathrm{~mm}$ in diameter, cut from the edge of 4-day-old Diaporthe culture, were placed at the end of the main leaf vein. The mycelium was firmly in contact with the upper surface of the lamina. Aluminum foil protected the infection court from drying. Three plants per genotype and two adjacent leaves per plant were inoculated.

First symptoms, in the form of chlorosis, were observed five days after inoculation in both isolates. First symptoms of necrosis occurred on the eight day, when the material was first assessed. Further assessments were made at eight-day inter- 
vals, so each plant was assessed five times in total. The assessments were made using the scale from 0-10:

0 no attack

1 necrosis barely visible on leaves $(1 \mathrm{~cm})$;

2 necrosis covering $1 / 4$ of leaf surface;

3 necrosis covering $1 / 3$ of leaf surface;

4 necrosis covering $1 / 2$ of leaf surface;

5 necrosis covering $2 / 3$ of leaf surface;

6 necrosis covered the entire lamina;

7 necrosis covered the lamina and the petiole;

8 the infected axillae not merged;

9 brown spot encircling the stem;

10 the stem broken at the encircling spot.

\section{RESULTS AND DISCUSSION}

A preliminary study of the isolates $\mathrm{Yu} 4$ and Yu 12 made at INRA-SGAP, Mauguio, together with some other French isolates, showed that these two isolates were significantly different regarding the radial growth in Petri dish, indicating their different origins (Table 1).

Table 1: Radial growth of the isolates $72 \mathrm{~h}$ after embedding (Ziercher, 1998)

\begin{tabular}{lccc}
\hline Newman-Keuls grouping & Radial growth of isolates $(\mathrm{cm})$ & Isolate & Origin \\
\hline A & 6.18 & 95050 & France \\
A & 5.68 & 96001 & France \\
A & 5.36 & 97002 & France \\
A B & 5.06 & 97001 & France \\
A B & 5.02 & Yu 12 & Yugoslavia \\
A B & 4.6 & 95004 & France \\
B C & 3.46 & 95049 & France \\
C & 2.68 & Yu 4 & Yugoslavia \\
D & 0.92 & 95031 & France \\
\hline
\end{tabular}

Figures 1-4 present intensities of Phomopsis attack 16, 24, 32 and 40 days after infection. Each genotype was assessed for average attacks, on all plants and on successfully inoculated leaves. Sixteen days after inoculation, Phomopsis attack was present only on leaves, the maximum intensity being the necrosis covering $2 / 3$ of leaf surface. After 24 days, first symptoms could be seen on petioles and in leaf axils. Brown spots encircling the stem were first observed 32 days after inoculation. Forty days after inoculation, the number of genotypes with symptoms on the petioles and stems was further increased. We did not observe a single case of plant lodging caused by Phomopsis infection.

Table 2: Average Phomopsis infection per day after inoculation with isolates Yu 4 and $\mathrm{Yu}$ 12, and correlations between them

\begin{tabular}{|c|c|c|c|c|c|c|}
\hline \multirow{2}{*}{$\begin{array}{l}\text { Days after } \\
\text { inoculation }\end{array}$} & \multicolumn{2}{|c|}{ Isolate Yu 4} & \multicolumn{2}{|c|}{ Isolate Yu 12} & \multirow{2}{*}{$\begin{array}{l}\text { Correlation } \\
\text { between isolates }\end{array}$} & \multirow{2}{*}{ Sign-test } \\
\hline & $\bar{X} \pm s \bar{X}$ & Std.Dev. & $\bar{X} \pm s \bar{X}$ & Std.Dev. & & \\
\hline 8 days & $0.07 \pm 0.01$ & 0.26 & $0.09 \pm 0.02$ & 0.33 & 0.96 & $2.80^{\star \star}$ \\
\hline 16 days & $0.32 \pm 0.04$ & 0.68 & $0.43 \pm 0.05$ & 0.77 & 0.93 & $5.35^{\star \star \star}$ \\
\hline 24 days & $1.39 \pm 0.06$ & 0.97 & $1.48 \pm 0.07$ & 1.03 & 0.92 & $2.38^{*}$ \\
\hline 32 days & $2.37 \pm 0.11$ & 1.67 & $2.50 \pm 0.10$ & 1.55 & 0.95 & $3.58^{* * *}$ \\
\hline 40 days & $3.30 \pm 0.15$ & 2.33 & $3.51 \pm 0.14$ & 2.25 & 0.97 & $5.89^{\star \star \star}$ \\
\hline
\end{tabular}


Normally, the highest average attacks and standard deviations for both isolates were observed 40 days after inoculation (Table 2 ).

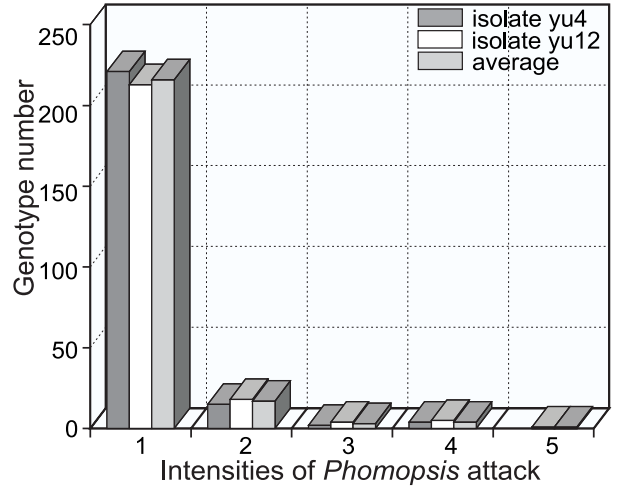

Figure 1: Intensities of Phomopsis attack 16 days after inoculation, for isolates Yu4, Yu12 and their average.

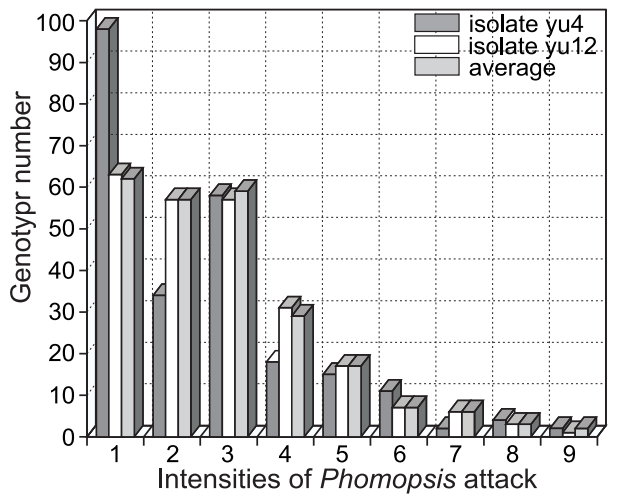

Figure 3: Intensities of Phomopsis attack 32 days after inoculation, for isolates Yu4, Yu12 and their average.

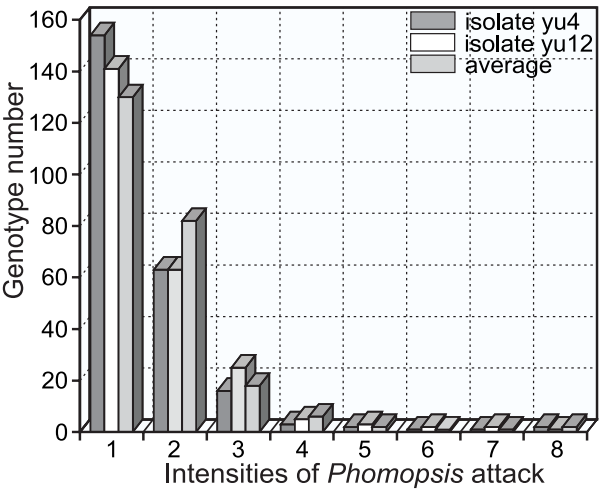

Figure 2: Intensities of Phomopsis attack 24 days after inoculation, for isolates Yu4, Yu12 and their average.

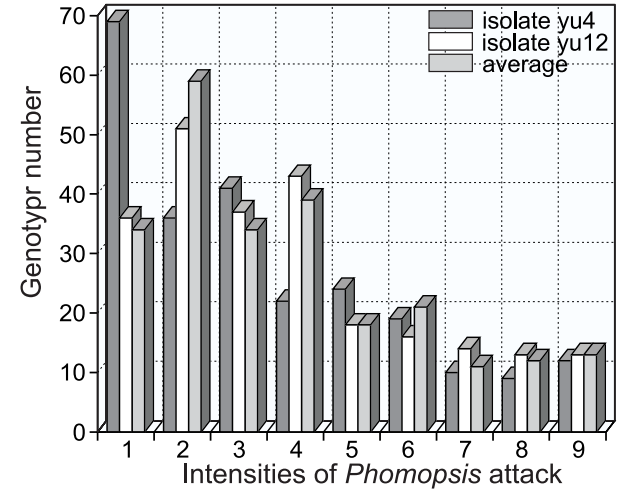

Figure 4: Intensities of Phomopsis attack 40 days after inoculation, for isolates Yu4, Yu12 and their average.

Generally, the intensity of attack was low, even though the inoculation success was very high, indicating that the environmental conditions in the greenhouse were not favorable for disease development. Correlations between Phomopsis inoculation with the isolates $\mathrm{Yu} 4$ and $\mathrm{Yu} 12$ were positive and very high (0.92-0.97) for all assessed days. This meant that no significant line $\times$ isolate interactions existed between the isolates. Still, the average Phomopsis infection with the isolate Yu 12 was slightly higher for all assessed days. The sign-test showed that significant differences existed in median values, indicating that the two isolates differed in aggressiveness.

Figures 5-8 present rates of Phomopsis development measured 16, 24, 32 and 40 days after inoculation, for the isolates $\mathrm{Yu} 4$ and $\mathrm{Yu}$ 12. The maximum rate of 
Phomopsis development soon after inoculation was 3.5. Later on, the maximum rate increased, especially between the $24^{\text {th }}$ and the $32^{\text {nd }}$ day when it reached 6 .

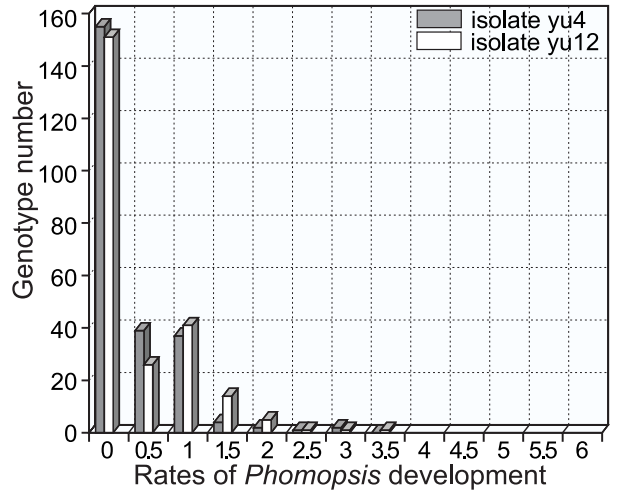

Figure 6: Rates of Phomospis development 24 days after inoculation, for isolates Yu4 and Yu12.

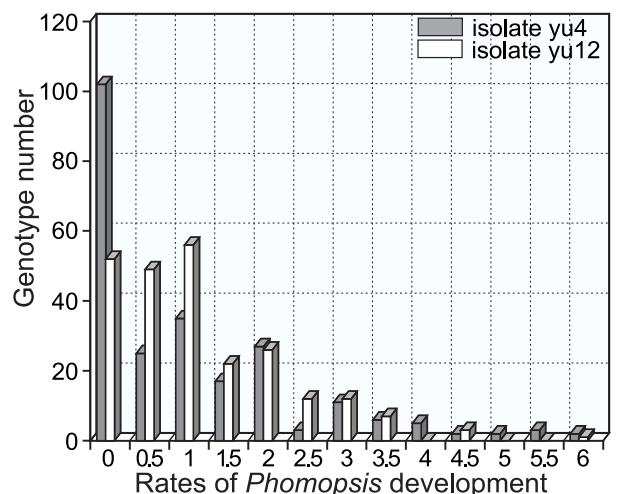

Figure 7: Rates of Phomospis development 32 days after inoculation, for isolates Yu4 and Yu12.

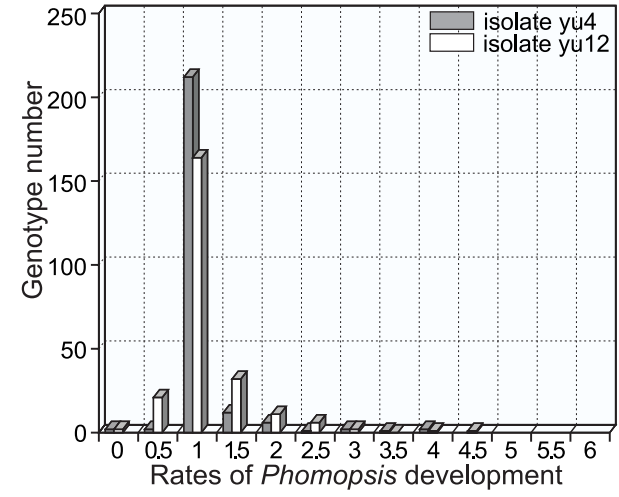

Figure 5: Rates of Phomospis development 16 days after inoculation, for isolates $\mathrm{Yu} 4$ and $\mathrm{Yu} 12$.

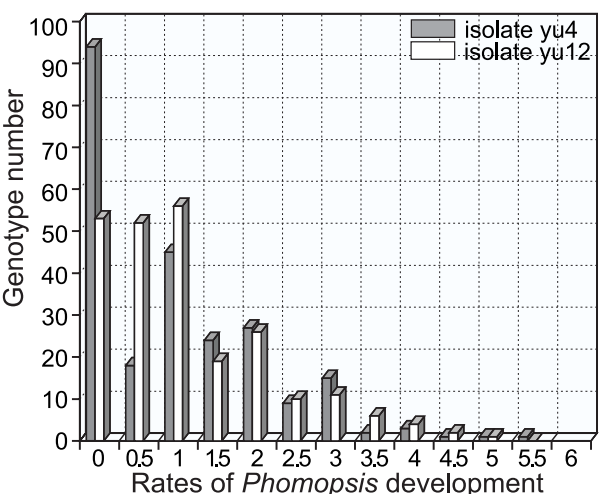

Figure 8: Rates of Phomospis development 40 days after inoculation, for isolates Yu4 and Yu12.

The average rate of Phomopsis development was lowest during first days after inoculation (Table 3).

Table 3: Average rates of Phomopsis development after inoculation with the isolates $\mathrm{Yu} 4$ and Yu 12 and correlations between them

\begin{tabular}{lccccc}
\hline \multirow{2}{*}{ Interval } & \multicolumn{2}{c}{ Isolate Yu 4 } & \multicolumn{2}{c}{ Isolate Yu 12 } & \multirow{2}{*}{$\begin{array}{c}\text { Correlation } \\
\text { between isolates }\end{array}$} \\
\cline { 2 - 4 } & $\bar{X} \pm s \bar{X}$ & Std.Dev. & $\bar{X} \pm s \bar{X}$ & Std.Dev. & 0.88 \\
\hline $8^{\text {th }}-16^{\text {th }}$ day & $0.25 \pm 0.03$ & 0.48 & $0.34 \pm 0.03$ & 0.54 & 0.65 \\
$16^{\text {th }}-24^{\text {th }}$ day & $1.07 \pm 0.03$ & 0.40 & $1.05 \pm 0.03$ & 0.48 & 0.90 \\
$24^{\text {th }}-32^{\text {th }}$ day & $0.99 \pm 0.08$ & 1.32 & $1.03 \pm 0.06$ & 1.02 & 0.85 \\
$32^{\text {th }}-40^{\text {th }}$ day & $0.93 \pm 0.07$ & 1.08 & $1.00 \pm 0.06$ & 1.02 & 02 \\
\hline
\end{tabular}


From the $16^{\text {th }}$ day to the $40^{\text {th }}$ day, the average rate remained at the same level. Correlations between the average rates of fungus development with the isolates $\mathrm{Yu} 4$ and $\mathrm{Yu} 12$ were positive and very high. The lowest correlation was found on the $24^{\text {th }}$ day (0.65). Correlations were similar for the other periods, from 0.85 to 0.90 .

\section{CONCLUSION}

The results of this study showed that there were no significant differences between the two isolates of Phomopsis helianthi, $\mathrm{Yu} 4$ and $\mathrm{Yu} 12$. The reason for the intensive attack recorded in 1997 in the area near the Danube River, were specific environmental conditions favorable for development of the disease.

\section{REFERENCES}

Aćimović, M. and Štraser, N., 1981. Phomopsis sp.-a new parasite in sunflower, Helia 4: 43-58 Degener, J., Melchinger, E.A. and Hahn, V., 1999. Inheritance of resistance to Phomopsis in sunflower: Study of leaf and stem resistance after artificial and natural infection, Helia 22(31): 105-115.

Maširević, S., Forgić, G. and Kurjak, N., 1998. Sunflower disease the main limiting factors in sunflower production in 1997, A Periodical of Scientific Research on Field and Vegetable Crops, Novi Sad, Yugoslavia, Vol. 30.

Langar, K., Griveau, Y., Vares, D. and Berville, A., 1997. Evaluation of resistance to Phomopsis (Diaporthe helianthi Munt.-Cvet. et al.) on wild species, cultivars and inbreds of sunflower (Helianthus spp.) with artificial and seminatural infections, Proceedings of the $10^{\text {th }}$ Mediterranean Phytopathological Union, Montpellier, France, pp 831-836.

Langar, K., Griveau, Y., Serieys, H. and Berville, A., 2000. Analyse genetique de la resistance au Phomopsis (Diaporthe helianthi Munt. -Cvet. et al) chez le tournesol cultive (Helianthus annuus L.), Proceedings of the $15^{\text {th }}$ International Sunflower Conference, Toulouse, France, Tome II, K-90-95.

Mihaljčević, M., Petrov, M. and Muntañola-Cvetković, M., 1980. Phomopsis sp.-a new parasite of sunflower in Yugoslavia, Savremena poljoprivreda 11-12: 531-540.

Mihaljčević, M., Muntañola-Cvetković, M. and Petrov, M, 1982. Further studies on the sunflower disease caused by Diaporthe (Phomopsis) helianthi and possibilities of breeding for resistance, Proceedings of the $10^{\text {th }}$ International Sunflower Conference, Surfers Paradise, Australia, pp 157-159.

Muntañola-Cvetković, M., Mihaljčević, M. and Petrov, M., 1981. On the identity of the causative agent of a serious Phomopsis-Diaporthe disease in sunflower plants, Nova Hedwigia 34: 417-435.

Škorić, D., 1985. Sunflower breeding for resistance to Diaporthe/Phomopsis helianthi Munt.Cvet. et al., Helia 8: 21-24.

Tourvieille, D., Vear, F. and Pelletier, C., 1988. Use of two mycelium tests in breeding sunflower resistant to Phomopsis, Proceedings of the $12^{\text {th }}$ International Sunflower Conference, Novi Sad, Yugoslavia, Vol. II, pp 110-114.

Vranceanu,, A.V., Craiciu, D., Soare, G., Pacureanu, M., Voinescu, G. and Sandu, I., 1992, Sunflower genetic resistance to Phomopsis helianthi attack, Proceedings of the $13^{\text {th }}$ International Sunflower Conference, Pisa, Italy, Vol. II, pp 1301-1306.

Ziercher L., 1998, Etude de l'interaction hôte-parasite dans la résistance du tournesol (Helianthus annuus L.) au phomopsis (Diaporthe helianthi Munt. Cvet et al.) Mémoire ENESAD Dijon (France). 


\title{
PRUEBA DE DOS AISLADOS DEL HONGO Diaporthe/ Phomopsis helianthi EN POBLACIÓN DE LAS LÍNEAS CONSANGUÍNEAS (INBRED) RECOMBINANTES DE GIRASOL
}

\author{
RESUMEN
}

El estudio fue realizado con el objetivo de averiguar la posibilidad del desarrollo de nuevos aislados más agresivos del hongo Phomopsis helianthi en Serbia y Montenegro. Se investigaron dos aislados, Phomopsis helianthi, Yu 4 y Yu 12. Dichos aislados se encontraron en el tallo del NS-H-45, un híbrido de alta tolerancia de girasol. El aislado Yu 4 fue aislado en el norte de Voivodina, en la región en la cual el ataque de Phomopsis usualmente está presente. El aislado Yu 12 viene de la parte meridional de Voivodina, de la región de la cuenca de Danubio, en la cual en el ano 1997 fue notado un fuerte ataque de Phomopsis. Una investigación preliminar de los aislados Yu 4 y Yu 12 demostró que los mismos eran significativamente diferentes desde el punto de vista de la extensión radial del hongo en las placas Petri. La prueba fue realizada con las líneas consanguíneas (inbred) recombinantes en la generación $\mathrm{F}_{9}$ derivadas del cruzamiento LR-4-17 (la línea consanguínea (inbred) con alta tolerancia a Phomopsis) y HA-89 (línea consanguínea (inbred) sensible). Los ensayos fueron realizados en las condiciones de invernadero, y las hojas fueron inoculadas por el micelio. Esta investigación demostró que entre los aislados investigados, Phomopsis helianthi, Yu 4 y Yu 12, no había diferencias significativas. Las razones para el ataque intensivo del ano 1997 en la cuenca de Danubio, eran las condiciones atmosféricas favorables para el desarrollo de la enfermedad en esa parte de Serbia y Montenegro.

\section{EXAMEN DE DEUX ISOLATS DE CHAMPIGNONS Diaporthe/Phomopsis helianthi DANS UNE POPULATION DE LIGNÉES DE TOURNESOL RECOMBINANTES}

\author{
RÉSUMÉ
}

Cette étude a été effectuée dans le but de vérifier la possibilité de développement de nouveaux isolats plus agressifs de Phomopsis helianthi en Serbieet-Monténégro. Deux isolats de Phomopsis helianthi, YU 4 et Yu 12 ont été examinés. Ces isolats avaient été trouvés sur la tige de NS-H-45, un hybride de tournesol très tolérant. L'isolat Yu 4 a été isolé dans la partie nord de la province de Vojvodine, une région habituellement touchée par le Phomopsis. L'isolat $\mathrm{Yu} 12$ vient de la partie sud de la province de Vojvodine, dans la région située le long du Danube et qui avait été touchée par une attaque virulente de Phomopsis en 1997. Des études préliminaires des isolats Yu 4 et Yu 12 ont démontré que ces deux isolats se différenciaient significativement pour ce qui est de la propagation radiale dans des plats Petri. Des tests ont été effectués avec les lignées recombinantes dans la génération $\mathrm{F}_{9}$ développée du croisement de LR-4-17 (lignée à grande tolérance au Phomopsis) et HA-89 (lignée sensible). Les expériences ont été effectuées dans les conditions de serre, l'inoculation artificielle de l'infection a été faite sur les feuilles des plantes avec du mycélium. Les résultats de cette étude n'ont pas démontré de différences significatives entre les deux isolats de Phomopsis helianthi, Yu 4 et Yu 12. Les raisons de l'attaque virulente de 1997 dans la vallée du Danube étaient des conditions météorologiques favorables au développement de la maladie dans cette région de Serbie-et-Monténégro. 